\title{
AFLATOXIN RESIDUES IN BACON PIGS
}

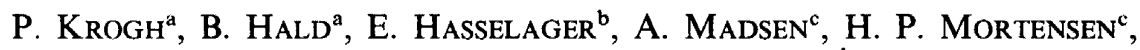
A. E. LARSEN ${ }^{c}$ and A. D. CAMPBELL ${ }^{d}$

(a) Institute of Hygiene and Microbiology and

(b) Department of Pharmacology and Toxicology of the Royal Veterinary and Agricultural University, Copenhagen, Denmark

(c) Department for Experiments with Pigs, National Institute of Animal Science, Copenhagen, Denmark

(d) Division of Food Chemistry and Physics, Food and Drug Administration, Washington, DC, USA

\begin{abstract}
Bacon pigs were fed diets containing 300 and $500 \mathrm{ppb}$ aflatoxin $\mathrm{B}_{1}+\mathrm{B}_{2}$ during a long period (120-231 days). When organs and tissues were examined for residues, sizable amounts of aflatoxin (max. $54 \mathrm{ppb}$ ) were detected. Since macroscopic alterations were slight in livers and absent in other organs and tissues, most livers and all other organs and carcasses could have passed meat inspection and been distributed for human consumption. This calls for careful control of animal feed, in order to avoid the use of heavily contaminated batches.
\end{abstract}

Information on aflatoxin residues in food of animal origin has so far been restricted to the excretion of aflatoxins, including aflatoxin $\mathrm{M}$, in the milk of lactating animals. Purchase ${ }^{1}$ has recently reviewed this aspect extensively. Although aflatoxin has been found in liver and kidney of small laboratory animals after a single dose of aflatoxin, attempts to detect aflatoxin in organs and carcasses of farm animals have mainly been unsuccessful. No aflatoxin residue was found in a pig that died of aflatoxicoses ${ }^{2}$, or in pigs fed various levels of aflatoxin up to $810 \mathrm{ppb}^{3}$. In cattle the same negative results were obtained $^{2,3}$ although the American team ${ }^{3}$ reported that traces of aflatoxin $B_{1}$ and $M_{1}$ were present in the blood of steers receiving a diet containing $1 \mathrm{ppm}$ aflatoxin. However, 'aflatoxin or aflatoxin metabolites' were found in muscle tissue of chickens fed aflatoxin ${ }^{4}$.

The problem of the transmission of mycotoxins through farm animals to the human food channel is very important, and may be especially pronounced for countries having extensive export of food of animal origin. Most of these countries, at least in Europe, are dependent upon an equally extensive import of feed, mostly from tropical and subtropical areas, and consequently this imported feed may be contaminated with mycotoxins, such as aflatoxin. 
This again involves control for aflatoxin in the imported feed. It seems that the exposure to aflatoxin in the Northern European countries is strictly associated with the importation of aflatoxin, as this particular mycotoxin is not produced in the colder climatic areas of Europe.

In order to elucidate the possibility of residues in Danish pigs fed aflatoxin an investigation was carried out. Pigs were continuously fed a ration containing aflatoxin-contaminated peanut meal (naturally contaminated with $2500 \mathrm{ppb}$ of aflatoxin $\mathrm{B}_{1}$ and $500 \mathrm{ppb}$ of $\mathrm{B}_{2}$ ) and studies were performed in order to detect aflatoxin residues in organs and carcasses.

Ten blocks of pigs of Danish Landrace, each comprising three castrated males and three females, were purchased at about eight weeks of age. Within each block the six animals were distributed in three experimental groups consisting of two pigs, one of each sex, thus resulting in 20 animals on each diet. During the pre-experimental period all pigs were fed a ration of barley and protein concentrates. From $20 \mathrm{~kg}$ up to slaughter at $90 \mathrm{~kg}$ live weight, the pigs were kept in individual pens with concrete floors and straw as bedding, and maintained at a temperature of $17^{\circ} \mathrm{C}$. Body weight was recorded at least every second week. Feed was weighed out daily. The pigs were fed twice a day, with daily feed allowance according to Table 1 . The composition of the diets is shown in Table 2. The three diets were analysed and selected results are presented in Table 3.

Table 1 . Daily feed allowance

\begin{tabular}{lllllll}
\hline Body weight (kg) & 20 & 30 & 40 & 50 & 70 & 90 \\
\hline Feed mixture (kg) & & & & & & \\
Diet 1 & 0.9 & 1.2 & 1.6 & 2.0 & 2.6 & 3.2 \\
Diet 2 & 0.9 & 1.2 & 1.6 & 1.9 & 2.4 & 2.8 \\
Diet 3 & 0.8 & 1.1 & 1.4 & 1.8 & 2.2 & 2.5 \\
\hline
\end{tabular}

Table 2. Composition of diets

\begin{tabular}{lccc}
\hline Ingredients & $\begin{array}{c}\text { Diet 1 } \\
(\%)\end{array}$ & $\begin{array}{c}\text { Diet 2 } \\
(\%)\end{array}$ & $\begin{array}{c}\text { Diet 3 } \\
(\%)\end{array}$ \\
\hline Barley & 77.6 & 83.2 & 81.5 \\
Soybean meal & 20.0 & - & - \\
Peanut meal & - & 10.6 & 16.0 \\
Meat and bone meal & - & 5.3 & $-\overline{0}$ \\
Sodium chloride & 0.4 & 0.4 & 0.4 \\
Calcium carbonate & 0.8 & 0.4 & 0.9 \\
Dicalcium phosphate & 1.1 & - & 1.1 \\
Vitamin-trace mineral mixture* & 0.1 & 0.1 & 0.1 \\
Total & 100.0 & 100.0 & 100.0 \\
\hline
\end{tabular}

*Each gramme contained: in I.U., vitamin A 3000; vitamin $\mathrm{D}_{3} 600$ : in mg, riboflavin 5 ; d-pantothenic acid 15 ; vitamin $\mathrm{B}_{12} 0.02$; alphatocopherol acetate 20; zinc oxide 100; copper sulphate 125; iron sulphate 125; manganese sulphate 125; cobalt sulphate 5; potassium iodide 1 . 
Table 3. Selected results of feed analysis

\begin{tabular}{lccc}
\hline Content & Diet 1 & Diet 2 & Diet 3 \\
\hline Lysine, $(\mathrm{g}$ per $16 \mathrm{~g} \mathrm{~N})$ & 5.5 & 4.0 & 3.7 \\
Methionine, $(\mathrm{g}$ per $16 \mathrm{~g} \mathrm{~N})$ & 1.6 & 1.5 & 1.4 \\
Aflatoxin $\left(\mathrm{B}_{1}+\mathrm{B}_{2}\right),(\mathrm{ppb})$ & 0 & 300 & 500 \\
\hline
\end{tabular}

During the experiment, the pigs fed diets 2 and 3 often showed loss of appetite. This was especially pronounced for 4 pigs, two of which died after 75 (diet 2) and 137 (diet 3) days at live weights of 41 and $24 \mathrm{~kg}$, respectively. After 156 and 170 days, two pigs on diets two and three at live weights of 53 and $52 \mathrm{~kg}$ were sacrificed for pathological examination.

During the period from 20 to $90 \mathrm{~kg}$ the pigs on diets two and three were much inferior to the pigs on diet one with respect to growth rate and feed conversion.

The pigs were fed for the last time at 7 a.m., as is the custom in Danish husbandry, and slaughtered at 11 a.m. the same day, at the same dressed weight $(64 \mathrm{~kg})$.

The pigs on diet one contained more meat and less fat than the pigs on diets two and three.

Whether the difference in carcass quality is due to the aflatoxin-contaminated feed cannot be evaluated on the basis of the present investigations.

At slaughter the pigs were inspected, and pieces of liver, kidney and heart were fixed in Lillie's neutral buffered formalin. Fixed tissues were processed for paraffin section and stained with iron hematoxylin van Gieson. At necropsy the livers of the pigs Nos. 1-12 and 19-26 (Tables 4 and 5) were slightly altered in the form of a slight cirrhosis, which did not cause rejection during meat inspection. The livers of the pigs Nos. 13-18 and 27-36 (Tables 4 and 5) had a yellow discolouration and rather pronounced cirrhosis; these livers would be rejected during meat inspection. All other organs, including the kidneys and all carcasses were free of any macroscopical alteration, and would therefore pass the meat inspection.

At histological examination, the livers showed a varied pathological picture, including cirrhosis, karyomegaly, atypical nuclei and proliferation of the bile ductules. The kidneys of some of the pigs (Tables 4 and 5) displayed microscopically a tubular degeneration consisting of very enlarged nuclei followed by cell desquamation.

Four of the twenty pigs (control) fed diet 1 were selected for pathological examination. No alteration was found in organs and tissues.

To detect aflatoxin, tissue samples of liver, kidney, heart, muscle and adipose tissue were extracted as follows. Samples of $100 \mathrm{~g}$ each of liver, kidney, heart and muscle were homogenized with $500 \mathrm{ml}$ of 70 per cent aqueous acetone, submerged in ice water to counteract the heat development, and extracted as described by Pons and Goldblatt ${ }^{4 a}$, modified by a further clean-up step on a silica gel column.

Samples of $50 \mathrm{~g}$ of adipose tissue were slurried with sand to a homogeneous mass, $250 \mathrm{ml}$ of chloroform and Celite 545 were added, and the mixture was 
P. KROGH ETAL.

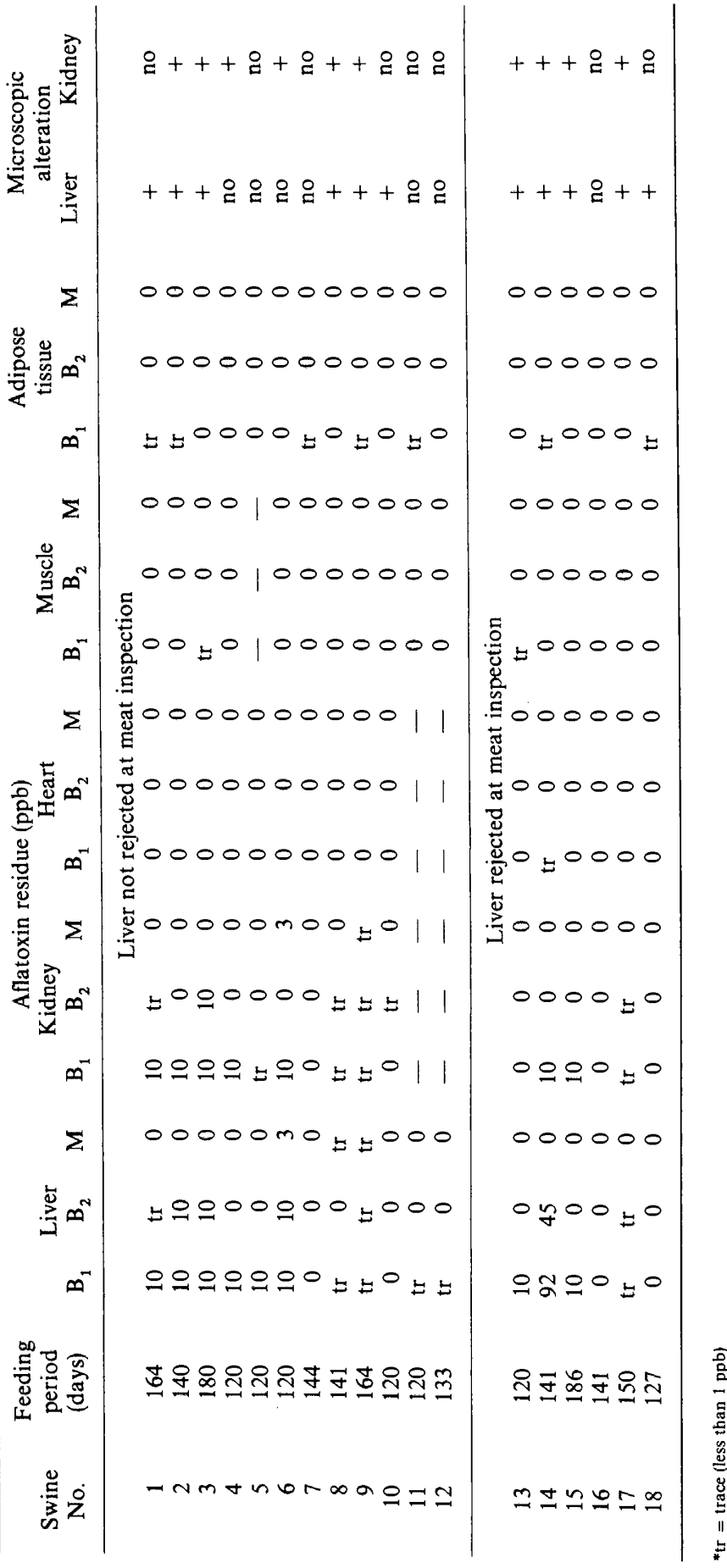


AFLATOXIN RESIDUES IN BACON PIGS

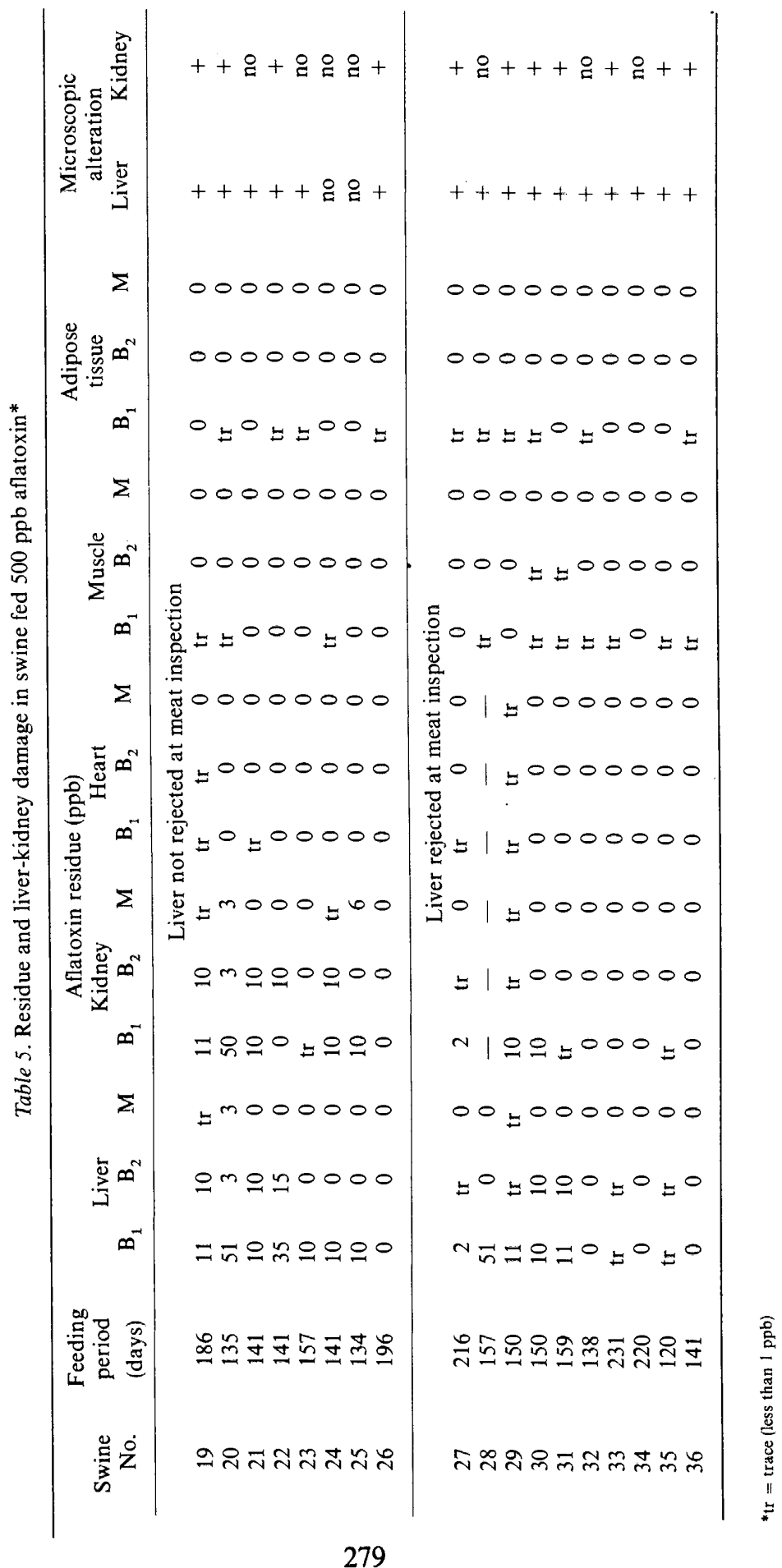


shaken and filtered. After evaporation to approximately $75 \mathrm{ml}$, the concentrate was placed on a silica gel column and washed with hexane and ethyl ether.

The toxins were eluted from the column with a methanol-chloroform mixture (3:97), and after evaporation to dryness quantification by t.l.c. on silica gel according to the IUPAC technique ${ }^{5}$ was carried out. Four solvents were used as mobile phases: chloroform-acetone $(9: 1)$, chloroform-methanol $(97: 3)$, benzene-ethanol-water $(46: 35: 19)$ and ethyl acetate-propanol-water $(10: 2: 1)$. Quantification was achieved by visual comparison, using qualitative standards of $B_{1}+B_{2}+G_{1}+G_{2}$, and $M_{1}$, as well as a quantitative standard of $B_{1}+G_{1}$.

A preliminary investigation of recovery of aflatoxin $\mathrm{B}_{1}$ added to homogenized liver tissue showed that 100 per cent recovery was obtained at the $1 \mathrm{ppb}$ level, whereas the recovery at the $0.5 \mathrm{ppb}$ level was less complete.

Various amounts of aflatoxin $B_{1}, B_{2}$ and $M$ were found in the livers and kidneys as well as traces in heart, muscle and adipose tissue of pigs fed diets 2 and 3 (Tables 4 and 5).

Tables 6 and 7 summarize the residues detected in organs and carcasses which would pass the meat inspection.

Table 6. Residues in liver and kidney

\begin{tabular}{|c|c|c|c|c|c|}
\hline & \multicolumn{2}{|c|}{ Diet 2} & & \multicolumn{2}{|c|}{ Diet 3} \\
\hline & mean & $\max$ & $\left(p p b B_{1}+B_{2}\right)$ & mean & $\max$. \\
\hline $\begin{array}{l}\text { Liver, accepted at meat } \\
\text { inspection }\end{array}$ & 8 & 23 & & 22 & 54 \\
\hline Kidney & 6 & 20 & & 10 & 53 \\
\hline
\end{tabular}

Table 7. Residues in other tissues

\begin{tabular}{lcc}
\hline Tissue & $\begin{array}{c}\text { Percentage of samples containing traces* } \\
\text { Diet } 2\end{array}$ & Diet 3 \\
\hline Heart & 5 & 22 \\
Muscle & 10 & 50 \\
Adipose & 35 & 50 \\
\hline
\end{tabular}

*trace $=$ less than $1 \mathrm{ppb}$

Among the four control pigs previously mentioned, three contained no aflatoxin in the organs and tissues investigated. The liver of the fourth pig contained traces of M-toxin, estimated on t.l.c. plates by comparison with a qualitative standard of M-toxin. Other organs and tissues contained no detectable aflatoxin. 
Results were confirmed by chemical tests, including derivative formation ${ }^{6}$ and ultraviolet spectroscopic examination of $B_{1}$ purified by thin-layer chromatography ${ }^{7}$. Bioassay confirmation included tests based on B. megaterium inhibition ${ }^{8}$, chicken-embryo toxicity ${ }^{9}$ and duckling bioassay ${ }^{10}$. All these tests confirmed the presence of aflatoxin, especially $\mathbf{B}_{1}$.

Bioassay including the chicken-embryo toxicity test and the duckling test, using extracts of the liver of one control pig, showed no toxicity reaction.

Thus it may be concluded that bacon pigs containing sizeable amounts of aflatoxin at slaughter are able to pass meat inspection because macroscopical alterations of organs and carcass are slight.

A similar problem has been encountered when ochratoxin-contaminated feed is used for bacon pigs ${ }^{11}$. This calls for careful control of animal feed, in order to avoid the use of heavily contaminated batches, because mycotoxins will be partly transmitted through slaughter animals into the human food channel.

\section{ACKNOWLEDGEMENTS}

We thank Dr N. C. Nielsen, Department of Special Pathology and Therapy, Dr A. Basse and Professor T. Møller, Department of Pathology, Royal Veterinary and Agricultural University, Copenhagen; Mr Robert Eppley, Dr M. Jacqueline Verrett and Mrs Judith Kautter, Food and Drug Administration, Washington, DC; Dr L. A. Goldblatt, US Department of Agriculture, New Orleans, La; and Dr I. F. H. Purchase, National Nutritional Research Institute, C.S.I.R., Pretoria, South Africa.

\section{REFERENCES}

${ }^{1}$ I. F. H. Purchase, Food Cosmet. Toxicol., 10 (4), 531 (1972).

2 R. Allcroft and R. B. A. Carnaghan, Vet. Rec. 75, 259 (1963).

3 A. C. Keyl and A. N. Booth, J. Am. Oil Chemists Soc., 48 (10), 599 (1971).

4 W. A. Van Zytveld, D. C. Kelley and S. M. Dennis, Poultry Sci., 49 (5), 1350 (1970).

ta W. A. Pons and L. A. Goldblatt, J. Am. Oil Chemists' Soc., 42 (6), 471 (1965).

${ }^{5}$ Provisional IUPAC method for aflatoxin in peanuts, peanut butter and peanut meal; IUPAC Information Bull., Nos. 31, 34 (1968).

6 L. Stoloff, J. Assoc. Offic. Anal. Chemists, 50 (2), 354 (1967); A. E. Pohland, L. Yin, J. G. Dantzman, ibid., 53 (1), 101 (1970).

7 J. A. Robertson, W. A. Pons and L. A. Goldblatt, J. Agr. Food Chem., 15, iyr (1967).

8 N. L. Clements, J. Assoc. Offic. Anal. Chemists, 51 (3), 611 (1968).

9 M. J. Verrett, J.-P. Marliac and J. McLaughlin, J. Assoc. Offic. Anal. Chemists, 47, 1003 (1964).

10 F. D. Asplin and R. B. A. Carnaghan, Vet. Rec., 73, 1215 (1961).

11 P. Krogh, personal communication (1972). 